\title{
Perceived Work-Life Interface and Organizational Citizenship Behavior: Are Job Satisfaction and Organizational Commitment Mediates the Relations? (Study on Star Hotels Employees in Indonesia)
}

\author{
Arif Partono Prasetio (Corresponding author) \\ School of Economics \& Business, Telkom University \\ J1 Telekomunikasi, Terusan Buah Batu, Bandung Indonesia \\ Tel: 085722767679Ｅ-mail: partono67@gmail.com
}

\begin{abstract}
Tjutju Yuniarsih
Faculty of Economic and Business Education, Indonesia University of Education Jl Setiabudhi No. 229, Bandung, Indonesia

Email: yuniarsih@upi.edu
\end{abstract}

Eeng Ahman

Faculty of Economic and Business Education, Indonesia University of Education Jl Setiabudhi No. 229, Bandung, Indonesia

Email: eengahman@yahoo.com

Received: Apirl 2, 2017 Accepted: April 16, 2017 Online published: April 21, 2017

doi:10.5296/ijhrs.v7i2.11099 URL: https://doi.org/10.5296/ijhrs.v7i2.11099

\begin{abstract}
The aim of the study is to examine the mediation of job satisfaction and organizational commitment in the relations between work-life interface and organizational citizenship behavior. This study use paper and pencil questionnaire which consists of 48 items and get response from 277 employees from 3-5 stars hotel in Bandung. To identify the relation between variables, this study using explanatory causal analysis which describe the causal
\end{abstract}


relation using hypothesis. Respondents selected using nonprobability sampling method with accidental technique. The result showed that positive and negative aspect of work-life interface (conflict and balance) has direct effect on OCB. Only job satisfaction has mediation effect in the relations. Hotel industry needs to apply human resources policies which focus on the supporting work and private life in order to increase the employees' satisfaction. In the end satisfied employees will contribute more to the organizations' achievement.

Keywords: Work-Life Interface, Organizational Citizenship Behavior, Job Satisfaction, Organizational Commitment.

\section{Introduction}

Every business has their target. Usually their goals increase every year. They want to win the competition or at least want to maintain their market in the highly competitive business environment. In order to achieve great performance organization need to manage their employees well. Employee is the heart and soul of a business. A business cannot run smoothly unless someone is doing the work. Organization needs good employees. Good employees can have great effect on sales and productivity (Nichols, 2006). In hotel industry the role of good human resources become more important, since the industry relies on service perform by human. Hotels need to have employees who perform well at all times and who not only do their job in the best possible way, but are also willing to do extra-role behaviors that can enhance their organizational effectiveness. Employees who perform extra-role behaviors are considered to have strong organizational citizenship behavior (OCB) and make their organization to strong in the competition (Hui, Lam, \& Law, 2000).

The present study examined the effect of the work-life interface on OCB using job satisfaction and organizational commitment as mediation in the hotel industry in Indonesia. According to Dorio et al (2008) research regarding work-family interface and OCB is still limited. In this research we also focus on two sides of the interface, negative (conflict) and positive (balance/enhancement). Rothbard (2001) mentions most of work-family research discuss the negative approach. In order to square up and broaden the study both sides of the interface should be conducted. We prefer use the term life as it has broader coverage than just family. After all, individual has life which goes beyond family (Keeney et al, 2013).

Because the study was conducted in Indonesia which has been part of eastern culture, it is expected to contribute in work-life interface literature which is usually dominated by the research from North America (western culture). The industry was chosen because hotel in Bandung, experienced fierce competition since 2012 (Hernasari, 2012; Lazuardi, 2014; Wadrianto, 2015). The number of hotel rooms has exceeded the demand. The occupancy rate for hotels has reached the point where the income from operations cannot cover the cost. Hotels involved in price-wars which will inflict financial loss. Hotels should rely on their service to attract customers. Employees with strong OCB would be the competitive advantage for them to achieve the target.

\section{Literature Review \& Hypotheses}

Greenhaus and Allen (2011) described the work-life interface as the intersection of work and 
private life. Private life includes aspects such as family, relatives, friends, leisure, social activities, and health. While work-life include aspects like work-hour, work-load, job descriptions, and certain targets. These two are bidirectional which mean each can interfere with other. Work-life conflict emerged if the interface is negative in nature, while work-life balance emerged once the interface resulting in positive situation (Greenhaus \& Allen, 2011). That is why it is important to always look at both interfaces when conducting research in work-life. The nature of work and life relation lies inside conservation of resources (COR) and social exchange theory. Emerson (1976) described social exchange as a series of interactions that generate obligations and such interaction is interdependent on the other another person action. While Hobfoll (1989) explained argued COR as the nature of individual who struggle to retain, protect, and build resources. Anything that is threatening to the effort of accumulating resources consider as potential loss of these valued resources.

Employee need to gather as much as possible resources to ensure that they it does not run out. Time, money, position, jobs are several of such resources seek by individual. Employee need to go to work to earn some money, but they sacrifice other resources (time). These result in chain reactions which accumulate or depleting depending on the future situation. COR explained why people become satisfied and more committed and willing to do more. Meanwhile social exchange theory supports the notion that positive actions from company could render employees' reciprocation. More policies from organization which benefit employee, they tend to become more attached and engaged. They will develop a positive inner feeling to give back (Organ \& Ryan, 1995). This extra-role behavior translated into the individual performance and also the organization.

\subsection{The Relations of Work-Life Interface, Job Satisfaction, Organizational Commitment, and $O C B$}

According to the previous discussion, we will review the work-life interface from both sides; conflict and balance. Gibson et al (2012) stated that company which provide work-life balance program have higher morale employee. One embodiment of such morale is the level of job satisfaction. A meta-analysis from Dorio et al (2008) found the negative effect between work and life interference on overall measures of job satisfaction. Amstad et al (2011) who also conduct meta-analysis study support the ideas regarding the negative relation between work-life conflicts on job satisfaction. This negative relation between work-life conflict (WLC) also found in studies from Pakistan, India, China, and Turkey (Akram \& Hasaan, 2013; Aryee et al, 2005; Gao et al, 2012; Ergenly et al, 2010).

A meta-analysis study from McNall et al (2010) who discussed the positive side of the interface argued that work-family enrichment positively affected job satisfaction. Azeem and Akhtar (2014) in India, Choi and Kim (2012) in Korea, found the positive relation between work-life balance and job satisfaction. Meanwhile, Haar et al, 2014 who conducted study using participants from Malaysia, New Zealand, Chinese, Spanish, French, and Italian proved that high level of work-life balance (WLB) associated with job satisfaction.

Based on the above review, the role of the work-life interface in promoting the job satisfaction was clear, so we hypothesized that: 
$\boldsymbol{H}_{1 a}:$ WLC have a significant negative effect on job satisfaction.

$\boldsymbol{H}_{1 b}:$ WLB have a significant positive effect on job satisfaction.

The relations between work-life interface and organizational commitment been widely studied. Allen et al (2000) reported that in regard of the negative interface the greater WLC resulted in less organizational commitment. Amstad et al. (2011) also indicated the negative effect size of WLC on organizational commitment. Other meta-analytic study from Meyer et al (2002) and Aryee et al (2005) found the same negative relationships. Researches from both eastern and western cultures provide the inline result. Most research revealed negative association between WLC and the organizational commitment. Some studies also discussed the positive association between WLB and organizational commitment. McNall et al (2011) found positive relation between work-family enrichment and affective commitment. Study from Malaysia by Omar (2013) argued positive relationship between work-life balance and affective commitment. The same positive direction also found by Sakhtivel \& Jayakrishnan (2012). The proposed hypotheses for the relation between work-life interface and organizational commitment are:

$\boldsymbol{H}_{2 a}:$ WLC have a significant negative effect on organizational commitment.

$\boldsymbol{H}_{2 b}:$ WLB have a significant positive effect on organizational commitment.

Next, we discuss the relation of work-life interface and OCB. Dorio et al (2008) indicated that there is a negative relationship between WLC and OCB. Result from Amstad et al (2011) and Tziner \& Sharoni (2014) found that work-family conflict was negatively related (-.39) with OCB. Meanwhile, Carlson et al (2013) using participants from western culture discussed the relationship between WLC, WLB and OCB. WLB had positive association with both OCB-I and OCB-O, while WLC had negative relationships with both OCB-I and OCB-O. Carlson divide the OCB into two parts concerning to other individual (OCB-I) and to organization (OCB-O). Regarding the positive side, Kasraie et al (2014) reveal the positive relation between QWL and OCB. Meanwhile, Baral and Bhargava in India (2010) also found positive association between work-life enrichment and OCB. Based on previous studies, we draw the hypotheses:

$\boldsymbol{H}_{3 a}: W L C$ ) have a significant negative relationship with $O C B$.

$\boldsymbol{H}_{3 b}:$ WLB have a significant positive relationship with $O C B$.

Social exchange, conservation of resources, and affective event theories can be used to explain the relation of work-life interface, job satisfaction, organizational commitment, and OCB. Happy employee, both at home and at work, tend to felt satisfied and more committed to the company. They felt obligated to payback to the company for the great work and life they had. They are willing to contribute more because they want to keep their resources. The cycle will repeat itself as long as employee felt the same. But, because of our human nature, employees may experience some fluctuation in their feeling, attitude, and behavior.

\subsection{Job Satisfaction, Organizational Commitment, and $O C B$}


Job satisfaction and organizational commitment often considered as antecedents of OCB. Most of the relations were in positive in nature. Whitman et al (2010), LePine et al (2002), Organ and Ryan (1995), and Dalal (2005) support positive relation between job satisfaction and OCB. Another meta-analysis focused on the relation between organizational commitment also found the significant positive relation. Positive relation found by Riketta (2002) and supported by the result from LePine et al (2002), Organ and Ryan (1995), and Dalal (2005). Studies carried out in non-Western culture conducted by Zeinabadi (2010) in Iran found that job satisfaction and organization commitment were positively correlated with OCB. Qamar (2012) from Pakistan revealed a positive relationship between both job satisfaction and organizational commitment on OCB. Research in Turkey (Sesen and Basim, 2012) and in Indonesia (Ngadiman, 2013) also showed positive correlations between job satisfaction and OCB.

The previous research demonstrates that job satisfaction and organization commitment have positive and significant relationships with OCB. This phenomenon can be explain using affective events theory (AET) from Weiss and Cropanzano (Thompson and Phua, 2012). AET described the role of emotion and evaluative judgment in the relationship between experiences and behavior. Employees' emotions and mental which combined with the incidents at work will affect their attitude and behavior. This reaction influences their job performance and satisfaction. Social exchange theory also can explain the relation. Social exchange involved unspecified obligations and there is element of trust (Cook \& Rice, 2002). The process of giving and receiving creates reciprocal conditions which underlie the on-going relations. Based on the previous literatures review we hypothesize that:

2.3 Mediation of Job Satisfaction and Organizational Commitment in the Relations of WLI and $O C B$

Research regarding the association between WLI and OCB still limited. One study who thoroughly analyzed the WLI, job satisfaction, organizational commitment, and OCB come from Tompson \& Werner (1997). The result show there was a direct negative relationship between inter-role conflict and OCB and job satisfaction did not mediate the relation. On the contrary, organizational commitment mediated the relation. Previous research which discussed the antecedents of OCB argued that job satisfaction and organizational commitment can predict OCB Dalal (2005), LePine et al (2002), Organ \& Ryan (1995), Riketta (2002), and Whitman et al (2010). These study, all revealed both variables predict the OCB. Furthermore, the relation of work-life interface to job satisfaction and organizational commitment presented by Amstad et al (2011), McNall et al (2010), Omar (2013), and Sakthivel \& Jayakrishnan (2012). They conclude that WLB associated with higher levels of job satisfaction and organizational commitment, while WLC associated with lower levels of job satisfaction and organizational commitment. Meanwhile, Netemeyer et al (2005) examined the potential mediators between WFC and OCB including job stress, organizational commitment, and job satisfaction. We argued that work-life interface have influences on job satisfaction and organizational commitment, which then these two predicts the OCB. We proposed the hypothesis as; 
$\boldsymbol{H}_{4 a}$ : There is negative indirect effect between WLC on OCB mediated by job satisfaction

$\boldsymbol{H}_{4 b}$ : There is negative indirect effect between WLC on OCB mediated by job satisfaction and organizational commitment

$\boldsymbol{H}_{4 c}$ : There is negative indirect effect between WLC on OCB mediated by organizational commitment

$\boldsymbol{H}_{5 a}$ : There is positive indirect effect between WLB on OCB mediated by job satisfaction

$\boldsymbol{H}_{5 b}$ : There is positive indirect effect between WLB on OCB mediated by job satisfaction and organizational commitment

$\boldsymbol{H}_{5 c}$ : There is positive indirect effect between WLB on OCB mediated by organizational commitment

\section{Methodology}

\subsection{Participant}

277 employees from 6 hotels in Bandung responded to the questionnaire. We have 85.2\% return rate from the 325 questionnaires distributed. Participants recruited with the permission of the hotel management. We choose six hotels in Bandung representing 3 to 5 stars based on the length of their operations. They have been in the business for more than 5 years. Data collected by means of paper and pencil survey. Questionnaires distributed to the employees who were on duty on the day we have the permission from management. Table 1 presented the detailed demographics of the participant.

Table 1. Participants' demographic

\begin{tabular}{cccc}
\hline $\begin{array}{c}\text { Demographics } \\
\text { Factors }\end{array}$ & Classification & $\begin{array}{c}\text { Number of } \\
\text { Repondents }\end{array}$ & Percentage \\
\hline Sex & Male & 188 & $68 \%$ \\
& Female & 89 & $32 \%$ \\
\hline Age & $<25$ & 63 & $23 \%$ \\
& $25-30$ & 62 & $22 \%$ \\
& $>30-35$ & 46 & $17 \%$ \\
& $>35-40$ & 41 & $15 \%$ \\
& $>40$ & 65 & $23 \%$ \\
\hline Education & High School & 125 & $45 \%$ \\
& Diploma & 45 & $16 \%$ \\
& Graduate & 74 & $27 \%$ \\
& Postgraduate & 33 & $12 \%$ \\
\hline Status & Married & 190 & $69 \%$ \\
& Single & 82 & $30 \%$ \\
& Separated & 5 & $2 \%$ \\
\hline
\end{tabular}

\begin{tabular}{cccc}
\hline \multirow{2}{*}{ Demographics Factors } & Classification & $\begin{array}{c}\text { Number of } \\
\text { Repondents }\end{array}$ & Percentage \\
\hline Children & No & 97 & $35 \%$ \\
& Yes & 180 & $65 \%$ \\
\hline Length of service & $<1$ year & 31 & $11 \%$ \\
& $1-3$ years & 63 & $23 \%$ \\
& $>3-5$ years & 40 & $14 \%$ \\
& $>5-10$ years & 65 & $23 \%$ \\
& $>10$ years & 78 & $28 \%$ \\
\hline Work hours & Up to 9 hours & 241 & $87 \%$ \\
& Over 9 hours & 36 & $13 \%$ \\
\hline Life Satisfaction & Very satisfy & 102 & $37 \%$ \\
& Satisfy & 92 & $33 \%$ \\
& In between & 80 & $29 \%$ \\
& Not satisfy & 3 & $1 \%$ \\
& Very Not satisfy & 0 & $0 \%$ \\
\hline & & &
\end{tabular}

Most of hotel employees are men (68\%). One hundred ninety are married (69\%) and 180 of them have children (65\%). Most of the participants (45\%) finished high school. Regarding the work-hour, most of them admitted they work only 9 hours a day. It was quite unique for hotels, but it certainly creates the work-life balance scheme. Age distribution seems prevalent. The good news for the organization is that they have $51 \%$ employees who worked for over 5 years. The length of service of employees indicates they have good experience in their jobs or companies. 


\subsection{Measurement}

Participants responded to all items for all variables using a five-point Likert scale which ranged from 1 (Strongly Disagree) to 5 (Strongly Agree). There were six items which need to be reverse (regarding the work-life conflict) when analyzing the data. Work-life interface was measured by a 9 item adapted from Hayman (2005). We have six items for WLC and three items for WLB. While job satisfaction assessed with 15 item scale adapted from Spector (1994). We used five dimensions; satisfaction with supervisor, income, career development, nature of work, and coworker relations. Organizational commitment measured based on the items created by Meyer and Allen (1991). OCB was measured using used five dimensions; altruism, courtesy, conscientiousness, sportsmanship, and civic virtue. There were 15 items for all dimension and develop based on William and Anderson concept (1991).

\subsection{Analysis Technique}

The study conducted using explanatory analysis which explains the relation of two variables or more. We used modified SPSS 21 to measure the relation of variables. Macro program (called PROCESS) installed on our SPSS will identify the relation between WLC and WLB on OCB through the mediation of job satisfaction and organizational commitment. Then, Bootstrapped Confidence Interval analysis developed by Hayes et al (2011) will show whether there are mediation or not. The rule to determine the mediation is that the Upper Level and Lower Level confidence interval does not contain zero value.

\section{Result \& Discussion}

We begin the discussion with the regression analysis of work-life conflict, job satisfaction, organizational commitment and OCB. Table 2 exhibit the statistical result for the relations of WLC, job satisfaction, organizational commitment, and OCB.

Table 2. Regression Coefficients, Standard Errors, and Model Summary Information for the WLC and OCB

\begin{tabular}{|c|c|c|c|c|c|c|c|c|c|}
\hline & \multicolumn{3}{|c|}{ Job Satisfaction } & \multicolumn{3}{|c|}{ Organizational Commitment } & \multicolumn{3}{|c|}{ OCB } \\
\hline & Coeff & SE & p-value & Coeff & SE & p-value & Coeff & $\mathrm{SE}$ & $\mathrm{p}$-value \\
\hline WLC & -0.395 & 0.035 & 0.000 & -0.124 & 0.050 & 0.018 & -0.110 & 0.031 & 0.000 \\
\hline Job Satisfaction & - & - & - & 0.907 & 0.071 & 0.000 & 0.500 & 0.055 & 0.000 \\
\hline \multirow[t]{2}{*}{ Organizational Commitment } & - & - & - & - & - & - & 0.071 & 0.037 & 0.055 \\
\hline & & $\begin{array}{l}\text { uare }=0 \\
=125,5 \\
=0,00\end{array}$ & & & $\begin{array}{l}\text { uare }=0 \\
=149,5 \\
=0,00\end{array}$ & & & $\begin{array}{l}\text { uare }= \\
=117,9 \\
=0,00\end{array}$ & \\
\hline
\end{tabular}

From the above table we can identify that all relations between variables were significant, except of one; organizational commitment and OCB $(p=0.055)$. We also noted the direction of the relation between WLC and the three variables were negative. This means that if employee experienced higher conflict they will have lower satisfaction commitment, and OCB. These results answer our hypothesis $\boldsymbol{H}_{1 a}, \boldsymbol{H}_{2 a}$, and $\boldsymbol{H}_{\mathbf{3} a}$. WLC has significant negative relation with job satisfaction, organizational commitment, and OCB. Now we turn to the positive interface, the WLB. Let's us look at the Table 3. 
Table 3. Regression Coefficients, Standard Errors, and Model Summary Information for the WLB and OCB

\begin{tabular}{lccccccccc}
\hline & \multicolumn{3}{c}{ Job Satisfaction } & \multicolumn{3}{c}{ Organizational Commitment } & \multicolumn{2}{c}{ OCB } \\
& Coeff & SE & p-value & Coeff & SE & p-value & Coeff & SE & p-value \\
\hline WLB & 0.180 & 0.030 & 0.000 & 0.168 & 0.032 & 0.000 & 0.005 & 0.022 & 0.807 \\
Job Satisfaction & - & - & - & 0.897 & 0.060 & 0.000 & 0.567 & 0.053 & 0.000 \\
Organizational Commitment & - & - & - & - & - & - & 0.088 & 0.039 & 0.026 \\
\hline & \multicolumn{3}{c}{$\mathrm{R}$ Square $=0,115$} & \multicolumn{3}{c}{ R Square $=0,556$} & & R Square $=0,545$ \\
& \multicolumn{3}{c}{$\mathrm{F}=35,801$} & \multicolumn{3}{c}{$\mathrm{F}=171,796$} & & $\mathrm{~F}=108,850$ \\
& $\mathrm{p}=0,000$ & $\mathrm{p}=0,000$ & & $\mathrm{p}=0,000$ \\
\hline
\end{tabular}

Table 3 showed different results. Here, most of the relations also found significant. Only one that does not show significant relation; WLB and OCB $(p=0.807)$. While higher conflict resulting in lower OCB, the more balance workers show no relation to OCB. This finding provide new paradigm for the company when they want to develop family or life supporting program. If they do not provide such program then, the employees felt conflict they can impact the OCB. On the contrary, if they provide such program, the do not get any positive result. Just to keep the level of conflict at an acceptable level. In our opinion, organization should develop work-life supporting programs, because they can still help the company to increase employee satisfaction and commitment, which then in the end could drive the OCB. Therefore our hypothesis $\boldsymbol{H}_{1 \boldsymbol{b}}$ and $\boldsymbol{H}_{2 b}$ were accepted but hypothesis $\boldsymbol{H}_{3 \boldsymbol{b}}$ was rejected.

Next we discuss whether the relations of WLC on OCB were mediated by job satisfaction and organizational commitment. Table 4 and 5 shows the direct, indirect, and total effect of WLC on OCB. The direct effect is negative and significant $(p=0,000)$, WLC has negative impact on OCB. The total effect (direct \& indirect) also shows the same direction. This finding reinforce that organization should prevent the level of conflict between work and life experienced by their employees. Programs such as day care, flexible work-hour, remote work, compensation based on family need, family gathering, spouses empowerment, family counseling can be applied. Regarding the indirect effect, this study found that only the first indirect effect (through job satisfaction) can be interpreted as significantly positive because the bootstrap confidence interval is entirely below zero $(-0,283$ to 0,132$)$. Employees who experience higher level of WLC perceived lower job satisfaction and this was associated with the lower OCB. The other two indirect effects (through job satisfaction and organizational commitment and through organizational commitment) cannot be considered as different from zero because both bootstrap confidence intervals were between $-0,060$ to 0,012 and $-0,031$ to 0,002 . The total effect is significantly positive at $-0,341$ and bootstrap confidence level does not contain zero $(-0,405$ to $-0,278)$.

Table 4. Total and Direct Effect of WLC and OCB

\begin{tabular}{cccccc}
\multicolumn{6}{c}{ Total Effect } \\
\hline Effect & SE & $\mathrm{t}$ & $\mathrm{p}$ & LLCI & ULCI \\
\hline$-0,341$ & 0,032 & $-10,566$ & 0,000 & $-0,405$ & $-0,278$ \\
\multicolumn{7}{c}{ Direct Effect } \\
\hline Effect & SE & $\mathrm{t}$ & $\mathrm{p}$ & LLCI & ULCI \\
\hline$-0,110$ & 0,031 & $-3,540$ & 0,001 & $-0,170$ & $-0,049$
\end{tabular}




\section{MInstitute Macrothink $_{\text {Int }}$}

International Journal of Human Resource Studies

ISSN 2162-3058

2017, Vol. 7, No. 2

Table 5. Indirect Effect of WLC and OCB through job satisfaction and organizational commitment

\begin{tabular}{|c|c|c|c|c|}
\hline & Effect & Boot SE & BootLLCI & BootULCI \\
\hline Total & $-0,232$ & 0,031 & $-0,297$ & $-0,177$ \\
\hline a. Through job satisfaction & $-0,197$ & 0,038 & $-0,283$ & $-0,132$ \\
\hline $\begin{array}{l}\text { b. Through job satisfaction \& } \\
\text { organzational commitment } \\
\text { b. Through organzational } \\
\text { commitment }\end{array}$ & $-0,026$ & 0,019 & $-0,060$ & 0,012 \\
\hline
\end{tabular}

Based on the above result we accept the hypothesis $\boldsymbol{H}_{4 a}$ that there is negative indirect effect between WLC on OCB mediated by job satisfaction. But the other two hypotheses, $\boldsymbol{H}_{4 \boldsymbol{b}}$ and $\boldsymbol{H}_{4 c}$ were rejected.

The results from the view of work-life balance somewhat different. Table 6 and 7 present the statistic result obtain from PROCESS. It is clearly that the direct effect is positive but not statistically significant $(p=0,807)$, this means the WLB does not affect the OCB. Whether employees perceived WLB or not does not change affect OCB. This finding is the opposite of the previous finding regarding WLC. These findings drown the viewpoint on WLC and WLB programs. On one side, company need to develop program to minimize the conflict of work and life with expectation to enhance OCB, but on the other side, such program which also expected to enhance WLB do not affect the OCB. Fortunately, WLB program still affect the job satisfaction which then functioned as mediation in the WLB and OCB relation which can increase OCB.

Related discussion on mediation, the result found the same pattern as of on the WLC discussion. Only job satisfaction mediates the relation. The indirect effect from WLB on OCB through job satisfaction can be interpreted as significantly positive since the bootstrap confidence interval does not contain zero $(0,059$ to 0,162$)$. The other two indirect effects both contain zero in their bootstrap confidence interval. Our hypotheses $\boldsymbol{H}_{5 \boldsymbol{a}}$ that there here is positive indirect effect between WLB on OCB mediated by job satisfaction is accepted. Hypotheses $\boldsymbol{H}_{5 b}$ and $\boldsymbol{H}_{5 c}$ were rejected.

Table 6. Total and Direct Effect of WLB and OCB

\begin{tabular}{cccccc}
\multicolumn{7}{c}{ Total Effect } \\
\hline Effect & SE & $\mathrm{t}$ & $\mathrm{p}$ & LLCI & ULCI \\
\hline 0,136 & 0,028 & 4,940 & 0,000 & 0,082 & 0,190 \\
& \multicolumn{5}{c}{ Direct Effect } \\
\hline Effect & SE & $\mathrm{t}$ & $\mathrm{p}$ & LLCI & ULCI \\
\hline 0,005 & 0,022 & 0,245 & 0,807 & $-0,038$ & 0,048
\end{tabular}

Table 7. Indirect Effect of WLB and OCB through job satisfaction and organizational commitment

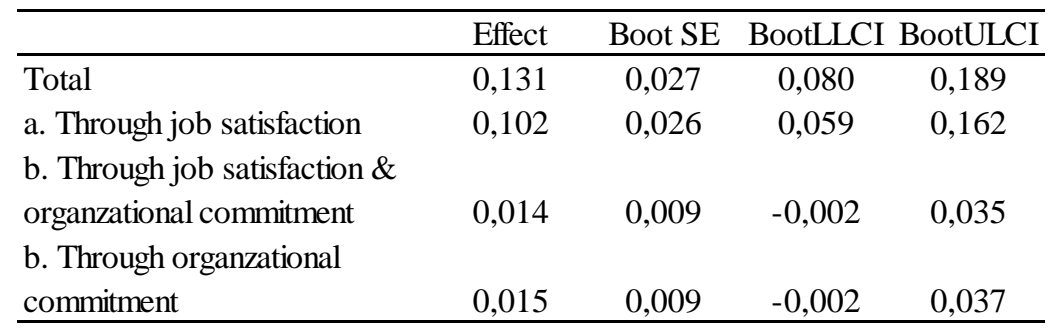




\section{Conclusion}

The result of the relation of WLC and OCB in present study, confirmed the notion of Dorio et al (2008), Amstad (2011), and Tziner and Sharoni (2014) who also found the significant negative effect of WLC (work-life interference) and OCB. On the contrary, the present study does not support the result previous research from Lambert (2000), Baral and Bhargava (2010), Kasraie et al (2014), and Pradhan et al (2016) who all found the significant positive relations. These results expand the field of OCB since there are no exact result regarding the relation of WLC and WLB. Such findings provide an overview that the study of work-life interfaces and OCB in various industries is needed. Organization need to know the best approach that can be applied to enhance OCB. Since the work-life and work-family support program become popular in organization, they also want to know what kind of program which suit their need.

The result also showed that job satisfaction play important role in mediating the relation of WLC and WLB on OCB. This means that organization should stay focus on how to make their employees satisfy. Good supervisor, decent and attractive jobs, appropriate salary, great work environment, and clear career advancement should be on their priority. Satisfied employees tend to stay longer and contribute more. They even developing outstanding performance beyond expectation. With such great performers, organization can have the benefit of competitive advantage which difficult to copy by their competitor. In this study, hotels management suggested to take care of the human assets, as they operated in service industry which depends largely on human touch. In time of fierce competition especially in pricing, they have to change their paradigm. Price-based competition would be detrimental to all parties. They need to have new arsenal to beat the enemy. To please their king, which is customer, they need to please the people who will serve the kings, the employee.

\section{Acknowledgement}

The research is funded by Ristekdikti through the program of Bantuan Seminar Luar Negeri 2016 which already presented in Brighton, United Kingdom on July 2016.

\section{References}

Akram, A. \& Hassaan, M. (2013). Impact of Work-Life Conflict on Job Satisfaction. Interdisciplinary Journal of Contemporary Research in Business, Vol. 5, No. 8, 434-448.

Allen, T. D., Herst, D. E. L., Bruck, C. S., \& Sutton, M. (2000). Consequences Associated With Work-to-Family Conflict: A Review and Agenda for Future Research. Journal of Occupational Health Psychology, 5(2), 278-308.

Amstad, F. T., Meier, L. L., Fasel, U., Elfering, A., \& Semmer, N. K. (2011). A meta-analysis of work-family conflict and various outcomes with a special emphasis on cross-domain versus matching-domain relations. Journal of Occupational Health Psychology, 16(2), 151-69. 
Aryee, S., Srinivas, E. S., \& Tan, H. H. (2005). Rhythms of life: antecedents and outcomes of work-family balance in employed parents. The Journal of Applied Psychology, 90(1), $132-46$.

Azeem, S. M., \& Akhtar, N. (2014). The Influence of Work Life Balance and Job Satisfaction on Organizational Commitment of Healthcare Employees. International Journal of Human Resource Studies, 4(2), 18-24.

Baral, R., \& Bhargava, S. (2010). Work-family enrichment as a mediator between organizational interventions for work-life balance and job outcomes. Journal of Managerial Psychology, 25(3), 274-300. http://doi.org/10.1108/02683941011023749

Carlson, D.S., Kacmar, K.M., Grzywacz, J.G., Tepper, B., \& Whitten, D. (2013). Work-Family Balance and Supervisor Appraised Citizenship Behavior: The Link of Positive Affect. Institute of Behavioral and Applied Management.

Choi, H. J., \& Kim, Y. T. (2012). Work-family conflict, work-family facilitation, and job outcomes in the Korean hotel industry. International Journal of Contemporary Hospitality Management, 24(7), 1011-1028.

Cook, K. S., \& Rice, E. R. W. (2002). Exchange and power: Issues of structure and agency. Handbook of Sociological Theory, (1974), 699-719. Retrieved from http://search.ebscohost.com/login.aspx direct=true $\& d b=$ sih $\& A N=18732580 \&$ site=ehost-live

Dalal, R. S. (2005). A meta-analysis of the relationship between organizational citizenship behavior and counterproductive work behavior. Journal of Applied Psychology, 90(6), 1241-1255.

Dorio, J. M., Bryant, R. H., \& Allen, T. D. (2008). Work-Related Outcomes of the Work-Family Interface: Why Organizations Should Care. In Handbook of Work-Family Integration (pp. 157-176).

Emerson, R. M. (1976). Social Exchange Theory. Annual Review of Sociology, 2, 335-362. http://doi.org/10.2307/2946096

Ergeneli, A., Ilsev, A., and Karapinar, P.Bayhan. (2010). Work-family Conflict and Job Satisfaction Relationship: The Roles of Gender and Interpretive Habits. Gender, Work and Organization, Vol. 17 No. 6, 679-695.

Gao, Y., Shi, J., Niu, Q., \& Wang, L. (2012). Work-Family Conflict and Job Satisfaction: Emotional Intelligence as a Moderator. Stress Health.

Gibson, J.L., Ivancevich, J.M., Donnelly Jr., J.H., \& Konopaske, R. (2012). Organizations: Behavior, Structure, Processes, 14th edition. New York: McGraw-Hill.

Greenhaus, J. H., \& Allen, T. D. (2011). Work-family balance: A review and extension of the literature. Handbook of Occupational Health Psychology (2nd Ed.)., (August), 165-183. 
Haar, J.M., Russo, M., Sune, A., Ollier-Malaterre, A. (2014). Outcomes of Work-life Balance on Job Satisfaction, Life Satisfaction and Mental Health: a Study across Seven Cultures. Journal of Vocational Behavior. Accepted Manuscript.

Hayes, A. F., Preacher, K. J., \& Myers, T. a. (2011). Mediation and the estimation of indirect effects in political communication research. In Sourcebook for political communication research: Methods, measures, and analytical techniques (pp. 434-465).

Hayman, J. (2005). Psychometric Assessment of an Instrument Designed to Measure Work Life Balance. Research and Practice in Human Resource Management, 13(1), 85-91.

Hernasari, P.R. (2012). Ketika Persaingan Hotel di Bandung Makin Keras. https://travel.detik.com/read/2012/10/22/173524/2069624/1382/ketika-persaingan-hotel-di-ba ndung-makin-keras. Accessed February 2017.

Hobfoll, S. E. (1989). Conservation of resources. A new attempt at conceptualizing stress. The American Psychologist, 44(3), 513-524.

Hui, C., Lam, S.S.K., \& Law, K.K.S. (2000). Instrumental values of organizational citizenship behavior for promotion: A field quasi-experiment. Journal of Applied Psychology, Vol 85(5), 822-828.

Kasraie, S., Parsa, S., Hassani, M., \& Ghasem-zadeh, A. (2014). The Relationship between Quality of Work Life, Job Stress, Job Satisfaction and Citizenship Behavior in Oshnaviyeh Hospital' s Staff Article history: Patient Safety \& Quality Improvement Journal, 2(3), $77-81$.

Keeney, J., Boyd, E. M., Sinha, R., Westring, A. F., \& Ryan, A. M. (2013). From "work-family" to "work-life": Broadening our conceptualization and measurement. Journal of Vocational Behavior, 82(3), 221-237.

Lambert, S. J. (2000). Added Benefits: The Link Between Work-Life Benefits and Organizational Citizenship Behavior. Academy of Management Journal, Vol. 43, No. 5, hlm. 801-815.

Lazuardi, I.T. (2014). Tingkat Hunian Hotel di Bandung Turun 20 Persen. https://m.tempo.co/read/news/2014/10/17/198614915/tingkat-hunian-hotel-di-bandung-turun20-persen. Accessed January 2017.

LePine, J. A., Erez, A., \& Johnson, D. E. (2002). The nature and dimensionality of organizational citizenship behavior: A critical review and meta-analysis. Journal of Applied Psychology, 87(1), 52-65.

McNall, L. A., Nicklin, J. M., \& Masuda, A. D. (2010). A meta-analytic review of the consequences associated with work-family enrichment. Journal of Business and Psychology, 25(3), 381-396.

Meyer, J. P., \& Alien, N. J. (1991). A three-component conceptualization of organizational commitment. Human Resource Management Review, 1(1), 61-89. 


\section{MInstitute Macrothink $_{\text {Int }}$}

International Journal of Human Resource Studies

ISSN 2162-3058

2017, Vol. 7, No. 2

Meyer, J. P., Stanley, D. J., Herscovitch, L., \& Topolnytsky, L. (2002). Affective, continuance, and normative commitment to the organization: A meta-analysis of antecedents, correlates, and consequences. Journal of Vocational Behavior, 61(1), 20-52.

Netemeyer, R. G., Maxham, J. G., \& Pullig, C. (2005). Conflicts in the Work-Family Interface: Links to Job Stress, Customer Service Employee Performance, and Customer Purchase Intent. Journal of Marketing, 69(2), 130-143.

Ngadiman. (2013). Influence of Work Satisfaction and Organizational Commitment to The Organizational Citizenship Behavior of Lecturers at Faculty of Teachers Training and Education, Sebelas Maret University, Surakarta. Educational Research International, Vol. 1 No. 3, pp 54-63.

Ngo, H.-Y., \& Lui, S. (2015). Gender Differences in Outcomes of Work-Family the Case of Hong Conflict : Sociological Focus, 32(3), 303-316.

Nichols, M. (2006). Great Employees Make A Great Business. https://www.bloomberg.com/news/articles/2006-03-30/great-employees-make-a-great-busine ss. Accessed March 2017.

Omar, M. K. (2013). Non Standard Work Arrangements and Affective Commitment: The Mediating Role of Work-life Balance. Procedia - Social and Behavioral Sciences, 107, 4-12.

Organ, D. W., \& Ryan, K. (1995). A Meta-Analitic review of Attitudinal and dispositional predictos of Organizational Citizenship Behavior. Personnel Psychology.

Pradhan, R.K., Jena, L.K., \& Kumari, I.G. (2016). Effect of Work-Life Balance on Organizational Citizenship Behaviour: Role of Organizational Commitment. Global Business Review, 17(3S) 1S-15S.

Qamar, N. (2012). Job Satisfaction and Organizational Commitment As Antecedent of Organizational Citizenship Behavior. Interdisciplinary Journal of Contemporary Research in Business, 4(7), 103-122.

Riketta, M. (2002). Attitudinal organizational commitment and job performance: A meta-analysis. Journal of Organizational Behavior, 23(3), 257-266.

Rothbard, N. P. (2001). Enriching or Depleting ? The Dynamics of Engagement in Work and Family Roles. Administrative Science Quarterly, 46(4), 655-684. http://doi.org/10.2307/3094827.

Sakthivel, D. \& Jayakrishnan, J. (2012). Work life balance and Organizational commitment for Nurses. Asian Journal of Business and Management Sciences, 2(5), 2-7.

Sesen, H., \& Basim, N. H. (2012). Impact of satisfaction and commitment on teachers' organizational citizenship. Educational Psychology, 32(4), 475-491. http://doi.org/10.1080/01443410.2012.670900

Spector, P.E. (1994). Job Satisfaction Survey. Department of Psychology, University of South Florida 


\section{Macrothink}

International Journal of Human Resource Studies

ISSN 2162-3058 2017, Vol. 7, No. 2

Thompson, E. R., \& Phua, F. T. T. (2012). A Brief Index of Affective Job Satisfaction. Group \& Organization Management, 37(3), 275-307.

Tompson, H. B., \& Werner, J. M. (1997). The Impact of Role Conflict/Facilitation on Core and Discretionary Behaviors: Testing a Mediated Model. Journal of Management, 23(4), 583-601.

Tziner, A., \& Sharoni, G. (2014). Organizational citizenship behavior, organizational justice, job stress, and work- family conflict: Examination of their interrelationships with respondents from a non-Western culture. Journal of Work and Organizational Psychology, 30(2), 35-42.

Wadrianto, G.K. (2015). Bisnis Hotel di Bandung Babak Belur, Kamar "Dijual" Rp 70.000 Per Orang. http://regional.kompas.com/read/2015/03/26/11215401/Bisnis.Hotel.di. Bandung.Babak.Belur.Kamar.Dijual.Rp.70.000.Per.Malam. Accessed February 2017.

Whitman, D. S., Van Rooy, D. L., \& Viswesvaran, C. (2010). Satisfaction, citizenship behaviors, and performance in work units: A meta-analysis of collective construct relations. Personnel Psychology, 63(1), 41-81.

Williams, L. J., \& Anderson, S. E. (1991). Job satisfaction and organizational commitment as predictors of organizational citizenship and in-role behaviors. Journal of Management.

Zeinabadia, H. (2010). Job satisfaction and organizational commitment as antecedents of Organizational Citizenship Behavior (OCB) of teachers. In Procedia - Social and Behavioral Sciences (Vol. 5, pp. 998-1003).

\section{Copyright Disclaimer}

Copyright for this article is retained by the author(s), with first publication rights granted to the journal.

This is an open-access article distributed under the terms and conditions of the Creative Commons Attribution license (http://creativecommons.org/licenses/by/4.0/). 